\section{In Situ Characterization of Fruits and Seeds of a Number of White Sapote (Casimiroa edulis Llave \& Lex.) Accessions in Mexico}

\author{
Jorge Andres Agustin \\ Centro Regional Universitario Centro Occidente, Universidad Autónoma \\ Chapingo, Av. Periférico Independencia Poniente 1000, C.P. 58170, Morelia, \\ Michoacán, Mexico
}

Matha Soto $^{1}$
Universidad Michoacana de San Nicolás de Hidalgo, Morelia, Michoacán,
México

Franco Famiani

Dipartimento di Scienze Agrarie, Alimentari e Ambientali, Universitá degli studi di Perugia, Borgo XX Giugno 74, 06121 Perugia, Italy

Juan Guillermo Cruz-Castillo ${ }^{2}$

Centro Regional Universitario de Oriente, Universidad Autónoma Chapingo, Km 6.2 Carretera Huatusco-Xalapa, Huatusco, Veracruz, 94100 Mexico

Additional index words. morphological variability, Casimiroa fruit quality, fruit genetic resources, morphometry, underutilized fruit

\begin{abstract}
Fifty-six accessions of white sapote (Casimiroa edulis Llave \& Lex.) grown in situ in 11 municipalities in the state of Michoacán, Mexico, were characterized using 14 morphometric variables (six of fruit and eight of seed). There was a high $\mathrm{CV}$ for fruit weight $(0.50)$, the number of developed seeds (NDS) $(0.48)$, and total seed weight $(0.45)$. Principal component analysis (PCA) showed that the main differences among the $C$. edulis accessions were fruit weight, seed projected area, Feret diameter (FD), the length of polar and equatorial axes of the fruit, the number of undeveloped seeds (NUS), the NDS, hardness of the skin (HS), and total soluble solids content of the fruits. Three groups of accessions were determined by cluster analysis (CA). The first group was made up of 53 accessions with intermediate values of fruit size and seed size. The second group, comprising two accessions, had the lowest values of fruit size. The third group showed an outstanding individual with the highest values for fruit size/weight, seed weight, and total soluble solids. Through an in-depth examination of the genotypes of the first group, four genotypes were identified for their positive characteristics. The results indicate an extremely high variability in the fruit and seed characteristics produced by different trees/genotypes of white sapote in Mexico. Hence, an initial, preliminary individuation/ selection of five genotypes could be considered for the development of new cultivars for establishing white sapote orchards in Mexico.
\end{abstract}

The genus Casimiroa (Rutaceae) is a native of the subtropical regions of Mesoamerica. Ten species have been recognized, nine of which are present in Mexico and Central America (Chiang, 1989; Henry and Vera-Calleti, 2010). Because of the sweet flavor and medicinal properties of the fruit, $C$. edulis is the best known species and is cultivated around the world.

White sapote (C. edulis), or "zapote blanco" in Spanish, or "urhuata urapiti" in the Purhepecha

\footnotetext{
Received for publication 22 Aug. 2017. Accepted for publication 11 Oct. 2017.

We thank the Universidad Autónoma Chapingo for financial support.

${ }^{1}$ Biology student.

${ }^{2}$ Corresponding author. E-mail: jcruzcastillo@yahoo. com.
}

language in Michoacán, Mexico, is distributed throughout the subtropical frost-free areas of Mexico at altitudes of 1500 $2500 \mathrm{~m}$. In particular, it is found in the states of Michoacán, Guanajuato, Jalisco, Colima, Hidalgo, State of Mexico, Veracruz, Chiapas, Puebla, Tlaxcala, and México City, in areas with rainfall between 900 and $1300 \mathrm{~mm} \cdot$ year $^{-1}$ (González-Elizondo et al., 2012). White sapote is common in backyards, semicultivated areas, and wild areas (Andrés-Agustín, 1996; Martinez, 1951; Popenoe, 1920). In Mexico, the fruit is available from April to July. White sapote is propagated by seed and this leads to a wide variability among trees in Mexico. The fruit of $C$. edulis is harvested for fresh consumption and is frequently sold in local markets (Andrés-Agustín, 1996). The leaves and seeds of this species are used in traditional medicine as a sedative (Khaleel, 2002) and as antihypertensive (Vidal-López et al., 2017) and anticonvulsant (Satheesh, 2015) agents.

The origin of domestication of white sapote was in the Basin of Mexico, which started between 6800 and $2500 \mathrm{BC}$ and is similar to other fruits such as avocado (Persea americana) and black sapote (Diospyros digyna) (García, 2007; González, 2001). White sapote was used by the Aztecs who named this fruit species "Cochitzapotl" $(\operatorname{cochi}=$ sleep and tzapotl $=$ fleshy and sweet fruit) due to its sleep-inducing properties (Sahagun, 1990). During the colonial conquest, white sapote, along with other native fruit species, was displaced by the introduction of European fruit species (González, 2001; Martínez et al., 2013).

Trees of white sapote are $3-5 \mathrm{~m}$ high. The fruit is climacteric (Lozano-Grande et al., 2006) and can be round, oval, or ovoid. It can be $6.25-11.25 \mathrm{~cm}$ wide and up to $12 \mathrm{~cm}$ long. Its skin is greenish-yellow in color (Fig. 1). The pulp is edible and creamy-white or yellow with tiny yellow oil glands. Its flavor is sweet with a hint of bitterness. The fruit may have one to six white seeds $2.5-5 \mathrm{~cm}$ long and $1.25-2.5 \mathrm{~cm}$ wide, but often some seeds are underdeveloped and very thin (Morton, 1987).

Currently, white sapote is cultivated in subtropical areas throughout the world and in regions with a Mediterranean, tropical, or semiarid climate. The trees have been planted in the northern part of South America, the Caribbean region, Spain, Portugal, Southern France (Ahlawat et al., 2017), Italy (Rossini et al., 2002), Egypt (Abo-El-Ez et al., 2013), and Ethiopia (Satheesh, 2015). They are grown commercially on a small scale in New Zealand, Australia (Yamamoto et al., 2007), and South Africa. There are small plantings in California, Florida, Hawaii (Ahlawat et al., 2017), and experimental plantings in Israel (Nerd et al., 1990). White sapote has grown well in California since the early 1800 s (Schneider, 1986) when it was introduced by Franciscan monks and produces well in San Francisco (Thompson, 1972).

There are few studies on white sapote. It was introduced into the Negev desert of Israel and its tolerance to salinity was studied by Nerd et al. (1992). Other studies on white sapote regard the analysis of varietal differences in floral and fruit morphology (Yonemoto et al., 2001), the definition of an index for establishing harvesting time for 'Cuccio' (Yonemoto et al., 2006), the genetic diversity of cultivars using ISR analysis (Yamamoto et al., 2007), and the selection in Egypt of trees/ genotypes having outstanding yield and fruit quality (Abo-El-Ez et al., 2013). In addition, in Florida, cultivars of white sapote, such as 'Dade' and 'Smathers', have been developed and are cultivated in home gardens (Crane and Balerdi, 2016).

Although white sapote is a native of Mexico, information regarding the characteristics of the trees/genotypes growing in 

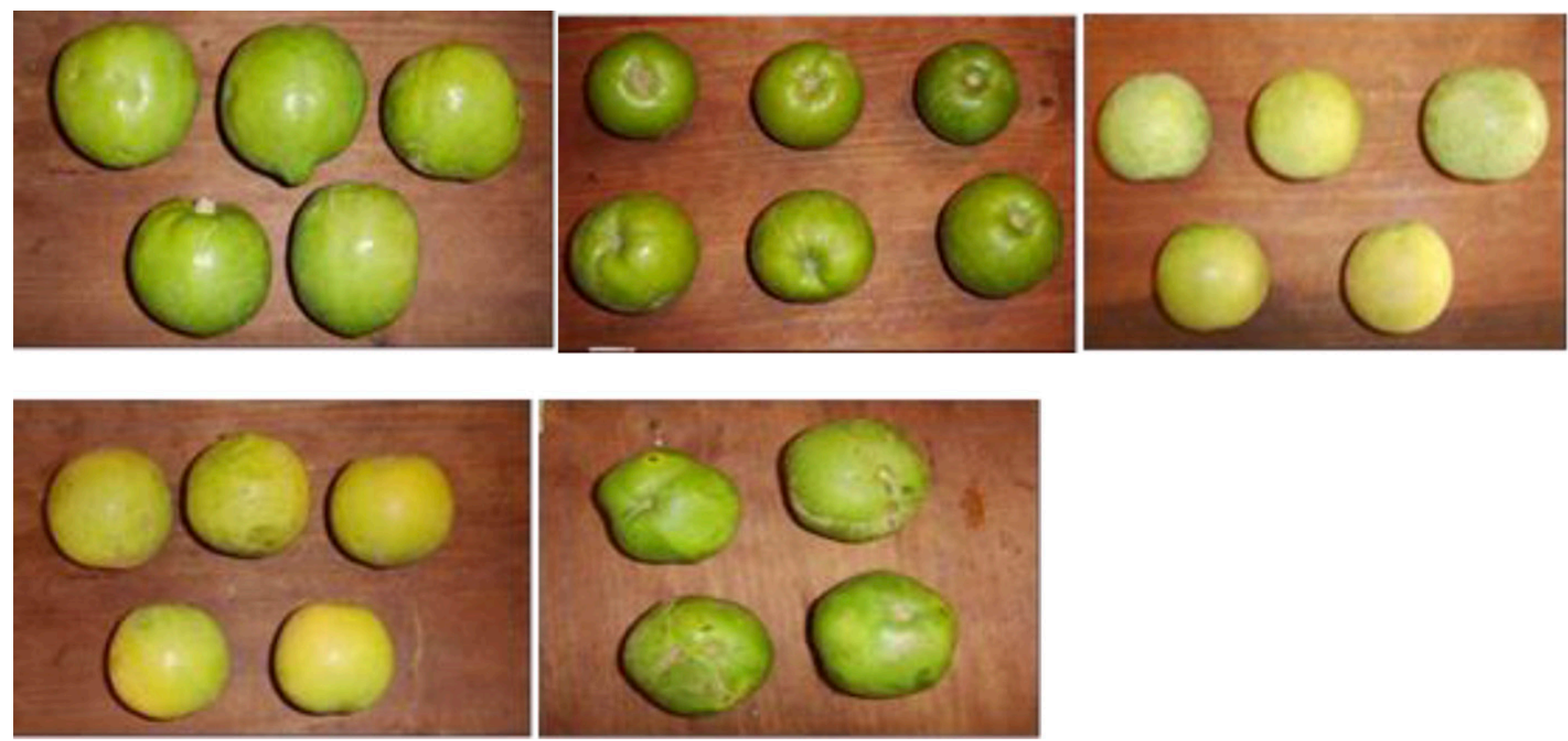

Fig. 1. Fruits of accessions 49, 17, 31 above (from left to right) and 48 and 41 below (from left to right) of white sapote (Casimiro edulis Llave \& Lex.) with outstanding characteristics and with the possibility of becoming registered cultivars.

Mexico is very limited and no data are available in peer reviewed literature. In addition, there are no Mexican cultivars of white sapote registered and there are no commercial plantings of this species in Mexico. As white sapote is well adapted to the environmental conditions of large areas of Mexico, as demonstrated by the fact that it grows wild, and considering that the consumption of its fruit and the medicinal interest in its seeds is increasing, it could be important to give more attention to this species in Mexico. In particular, it could be useful to provide information for its cultivation. In this regard, a fundamental aspect is the individuation/selection of superior genotypes in terms of adaptability and fruit and seed characteristics, which are fundamental for establishing orchards.

The purpose of this study was to characterize, in situ, the fruit and seed characteristics/ quality of a number of accessions growing in several municipalities of Michoacán, Mexico, to evaluate the variability of the genotypes that are present and to specify/select valuable genotypes that have potential for being registered as cultivars for future cultivation in Mexico.

\section{Materials and Methods}

Fruits were collected from 56 white sapote trees (accessions) growing in ten municipalities of Michoacán, Mexico, located between 1861 and $2400 \mathrm{~m}$ altitude: Morelia, Pátzcuaro, Lagunillas, Huiramba, Ziracuaretiro, Tangancícuaro, Purépero, Quiroga, Tzintzuntzan, and Los Reyes. For each accession, 10 fruits, at physiological maturity (LozanoGrande et al., 2006), were collected from April to June of 2015. A digital scale (Ohaus CS2000) balance was used to determine fresh fruit weight $(\mathrm{FW})$. The equatorial and polar diameters of the fruit $(\mathrm{cm})(\mathrm{EDF}$ and PDF, respectively) were measured with a digital caliper (Mitutoyo CD-6"CSX). To evaluate the HS a McCormick fruit pressure tester [FT $0011(0-11 \mathrm{lbs})]$ with a $11.2-\mathrm{mm}$ plunger was used. Total soluble solids (TSS) as ${ }^{\circ}$ Brix were determined with a hand refractometer $\mathrm{ABBE}^{\circledR} 117$ digital (Leica Mark II). Skin and seeds were separated from the pulp and weighed (SW) (g). The NDS and NUS were recorded. A random sample of 15 seeds per accession was weighed (TSW) and scanned in digital photographs using Image Tool Ver. 3.00 (UTHSCSA, 2000) to determine the following parameters of the seeds: projected area $\left(\mathrm{cm}^{2}\right)$ (SPA), the length of the equatorial diameter $(\mathrm{cm})(\mathrm{LEA})$, the length of the polar axis $(\mathrm{cm})(\mathrm{LPA})$, roundness index [(4. $\pi \cdot$ area)

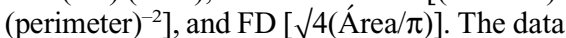
were elaborated using PCA and CA and the data were standardized (Rholf, 2000). For $\mathrm{CA}$, the similarity matrix among specimens was calculated using the average taxonomic distance (Manly, 1986). The unweighted pairgroup method arithmetic average was used for clustering. Numerical analyses were carried out with the software package NTSYS-pc version 2.1 (Rholf, 2000). These technics of multivariate data analysis are often used for characterizing vegetative or fruit parameters of wild fruits (Andrés-Agustín et al., 2006; Franco-Mora et al., 2008; López-Santiago et al., 2008). Standard errors of selected variables were determined with the Infostat software version 2017 (Di Rienzo et al., 2017).

\section{Results and Discussion}

Fruit weight, the NDS, and the total seed weight (TSW) were the variables with the highest CV. Values of FW were from $11.08 \pm$
$1.9 \mathrm{~g}$ to $323.68 \pm 8.1 \mathrm{~g}$. The NDS between 0 and 3 , and the TSW ranged from $1.16 \pm$ $0.09 \mathrm{~g}$ to $46.97 \pm 2.1 \mathrm{~g}$ (Table 1$)$.

The first three principal components (PCs) explained $53.33 \%, 13.80 \%$, and $9.89 \%$ of the variance, respectively, for a total of $77.02 \%$ (Table 2), and only these three components were used for interpreting the results because the eigenvalues were above 1 (Manly, 1986). The first PC was associated with fruit size and seed size. Thus, the main variables in this PC 1 were fruit $\mathrm{FW}$, seed weight per fruit (SW), PDF, EDF, total seed weight per accession (TSW), surface projected area of the seed (SPA), the length of the polar axis of the seed (LPA), the length equatorial of the seed (LEA), and FD. In the second PC, the NDS and the NUS were relevant. In the third PC, the highest scores were for HS and TSS (Table 3).

Three different groups were defined with the CA (Table 4). The first group included 53 individuals characterized by intermediate values of fruit size, seed size, and HS. These trees had average values of $\mathrm{FW}=100.56 \pm$ $5.45 \mathrm{~g}, \mathrm{HS}=1.67 \pm 0.60 \mathrm{~kg} \cdot \mathrm{cm}^{-2}, \mathrm{PDF}=5.36$ $\pm 0.12 \mathrm{~cm}$, and TSW $=19.30 \pm 1.10 \mathrm{~g}$. The second group included two accessions (11 and 44) characterized by fruit and seeds of small size and weight. For example, they had average $\mathrm{FW}$ values $=26.76 \pm 15.68 \mathrm{~g}, \mathrm{SW}=$ $3.59 \pm 0.21 \mathrm{~g}, \mathrm{EDF}=3.14 \pm 0.12 \mathrm{~cm}$, and $\mathrm{TSW}=3.59 \pm 2.02 \mathrm{~g}$. The third group consisted of only one tree which had the highest $\mathrm{FW}=323.69 \pm 8.1 \mathrm{~g}, \mathrm{HS}=2.32 \pm$ $0.80 \mathrm{~kg} \cdot \mathrm{cm}^{-2}, \mathrm{SW}=20.41 \pm 1.12 \mathrm{~g}, \mathrm{PDF}=7.97$ $\pm 0.99 \mathrm{~cm}, \mathrm{EDF}=8.53 \pm 1.0 \mathrm{~cm}, \mathrm{TSW}=23.60$ $\pm 2.0 \mathrm{~g}, \mathrm{SPA}=7.69 \pm 0.59 \mathrm{~cm}^{2}, \mathrm{LPA}=4.78 \pm$ $0.77 \mathrm{~cm}, \mathrm{LEA}=2.14 \pm 0.10 \mathrm{~cm}$, and $\mathrm{FD}=3.12$ \pm 0.04 values (Table 4 ).

The domestication of white sapote began $6800-2500 \mathrm{BC}$ in the Mesoamerican region at 
Table 1. Descriptive statistics of the 14 variables evaluated in 56 genotypes of white sapote (Casimiroa edulis Llave \& Lex).

\begin{tabular}{lrrrrrr}
\hline Variable & Mean & \multicolumn{1}{c}{ SD } & CV $(\%)$ & $N$ & Minimum & Maximum \\
\hline FW & 101.91 & 50.92 & 50.0 & 56 & 11.08 & 323.68 \\
HS & 1.65 & 0.54 & 32.7 & 56 & 0.25 & 2.93 \\
TSS & 18.70 & 3.39 & 18.1 & 56 & 11.20 & 26.83 \\
SW & 9.80 & 3.43 & 35.0 & 56 & 2.62 & 20.41 \\
PDF & 5.33 & 0.91 & 17.1 & 56 & 2.38 & 7.97 \\
EDF & 5.56 & 1.09 & 19.6 & 56 & 2.41 & 8.52 \\
NUS & 3.42 & 0.70 & 20.5 & 56 & 1.33 & 4.66 \\
NDS & 1.38 & 0.67 & 48.6 & 56 & 0.00 & 3.00 \\
TSW & 18.75 & 8.48 & 45.2 & 56 & 1.16 & 46.97 \\
SPA & 4.44 & 1.16 & 26.1 & 56 & 0.78 & 7.69 \\
LPA & 3.20 & 0.52 & 16.3 & 56 & 1.47 & 4.78 \\
LEA & 1.78 & 0.27 & 15.2 & 56 & 0.70 & 2.24 \\
SRI & 0.68 & 0.06 & 8.8 & 56 & 0.53 & 0.78 \\
FD & 2.34 & 0.34 & 14.5 & 56 & 0.99 & 3.12 \\
\hline
\end{tabular}

$\mathrm{FW}=$ fruit fresh weight; $\mathrm{HS}=$ hardness of the skin; TSS = total soluble solids; $\mathrm{SW}=$ seed weight per fruit; $\mathrm{PDF}=$ polar diameter of the fruit; $\mathrm{EDF}=$ equatorial diameter of the fruit; NUS = number of undeveloped seeds; NDS = number of developed seeds; TSW = total seed weight per accession; SPA $=$ surface projected area of the seed; LPA = length of the polar axis of the seed; LEA = length equatorial of the seed; SRI = seed roundness index; FD = Feret diameter.

Table 2. Eigenvalues, percent, and cumulative variance of the first three principal components (PCs) on 14 variables measured on white sapote (Casimiroa edulis Llave \& Lex) fruit and seeds.

\begin{tabular}{lccc}
\hline PC & Eigenvalue & Percent & Cumulative (\%) \\
\hline 1 & 7.4671 & 53.33 & 53.33 \\
2 & 1.9322 & 13.80 & 67.13 \\
3 & 1.3854 & 9.89 & 77.02 \\
\hline
\end{tabular}

Table 3. Eigenvector values on the first three axes after principal component (PC) analysis of fruit and seed of white sapote (Casimiroa edulis Llave \& Lex).

\begin{tabular}{lrrr}
\hline Character & \multicolumn{1}{c}{ PC 1 } & \multicolumn{1}{c}{ PC 2 } & \multicolumn{1}{c}{ PC 3 } \\
\hline FW & $\mathbf{0 . 8 7 9 0}^{z}$ & 0.0688 & 0.1174 \\
HS & 0.3783 & 0.1559 & $-\mathbf{0 . 6 3 9 8}$ \\
TSS & 0.0824 & 0.0785 & $-\mathbf{0 . 6 1 6 1}$ \\
SW & $\mathbf{0 . 7 8 2 2}$ & 0.1946 & 0.3053 \\
PDF & $\mathbf{0 . 9 0 4 4}$ & 0.0903 & 0.0986 \\
EDF & $\mathbf{0 . 9 1 3 6}$ & 0.1166 & -0.0211 \\
NUS & 0.3976 & $-\mathbf{0 . 8 2 3 5}$ & -0.2284 \\
NDS & -0.2300 & $\mathbf{0 . 8 6 5 3}$ & 0.2690 \\
TSW & $\mathbf{0 . 8 3 4 2}$ & -0.3134 & -0.0582 \\
SPA & $\mathbf{0 . 9 3 0 8}$ & 0.2193 & -0.0143 \\
LPA & $\mathbf{0 . 9 1 5 8}$ & 0.0651 & 0.1468 \\
LEA & $\mathbf{0 . 8 3 2 2}$ & 0.3250 & -0.2024 \\
SRI & -0.3423 & 0.3260 & -0.5342 \\
FD & $\mathbf{0 . 9 2 6 5}$ & 0.2194 & -0.0574 \\
\hline
\end{tabular}

${ }^{\mathrm{z}}$ Values in each PC with important contribution are in bold.

FW = fruit fresh weight; HS = hardness of the skin; TSS = total soluble solids; SW = seed weight per fruit; $\mathrm{PDF}=$ polar diameter of the fruit; $\mathrm{EDF}=$ equatorial diameter of the fruit; NUS = number of undeveloped seeds; NDS = number of developed seeds; TSW $=$ total seed weight per accession; $\mathrm{SPA}=$ surface projected area of the seed; LPA = length of the polar axis of the seed; LEA = length equatorial of the seed; $\mathrm{SRI}=$ seed roundness index; FD $=$ Feret diameter.

the end of the Lithic period and was parallel to the domestication of corn, squash, chili, avocado, black sapote, amaranth, beans, and cotton (García, 2007). Recently, Hernández (1993) reported that in Oaxaca, Mexico, white sapote is still in a transition process of domestication, but the fruit if of good quality is already being sold in local markets. In Michoacán, Mexico, white sapote grows wild in the Purhepecha and Nahua regions and human beings have influenced its variability, choosing trees to plant in home gardens that produce large-size fruit. However, specialized cultivations have not been established. To begin this process, it is necessary to select genotypes/new varieties well adapted to the environment that are able to produce high quality fruit that is appreciated by consumers. In this regard, the results of the present investigation showed that the fruit and seeds collected from white sapote trees growing in various places in Michoacán, Mexico, had a high variability in their characteristics. Tree number 49 (Fig. 1), located in Purepero, Michoacán, Mexico, was evaluated because it was recommended by the local people; it had the largest fruit size $(323.69 \mathrm{~g})$, with a high percentage of pulp $(86.40 \%)$, a good round form (symmetric) and a very colorful skin (yellowish-green). It also had the highest content of total soluble solids (Table 4). Moreover, there was only a minor physical damage to the skin caused by the larvae of Anastrepha sp. (Zavaleta and Engleman, 1991). The seeds were also large. Furthermore, other genotypes producing fruit with a good shape but slightly smaller than those of tree 49 were interesting for registration. These were numbers $17(\mathrm{FW}=186.94$ $\mathrm{g}), 31(\mathrm{FW}=143.65 \mathrm{~g}), 48(\mathrm{FW}=175.50 \mathrm{~g})$, and $41(\mathrm{FW}=193.10 \mathrm{~g})$ (Fig. 1). Yonemoto et al. (2001) characterized the fruit fresh weight of 17 cultivars of $C$. edulis cultivated ex situ in a glasshouse, and values were between 85 and $304 \mathrm{~g}$. In the semiarid climate of Egypt, seedlings of white sapote yielded fruit with fresh weight values between 53.10 and $133.7 \mathrm{~g}$ (Abo-El-Ez et al., 2013). Trees 49, $17,31,48$, and 41 had fruits larger or within the range found in such studies (Abo-El-Ez et al., 2013; Yonemoto et al., 2001). Regarding the SW (g), Yonemoto et al. (2001) found values between 5.8 and $24.4 \mathrm{~g}$ and Abo-El-Ez et al. (2013) between 6.10 and $20.50 \mathrm{~g}$. In the present study, the seed weights of the fruits of the five outstanding white sapote trees were between 10.89 and $20.41 \mathrm{~g}$. The TSS at harvest of these five $C$. edulis trees averaged
20.2 ${ }^{\circ}$ Brix, which was higher than those reported by Lozano-Grande et al. (2006) for fruits of white sapote collected in other regions of Mexico.

George et al. (1988) indicated that fruits of $C$. edulis suitable for commercial purposes should have a weight between 250 and $350 \mathrm{~g}$. Fruit of tree number 49 meets this requirement. Moreover, fruit of trees numbers 17, 31, 41, and 48 were slightly smaller than $250 \mathrm{~g}$, but it is likely that producing them under cultivation (i.e., applying cultural practices able to promote fruit growth), their weight is likely to increase up to values within the 250-350 g range.

Fruit size depends on the development of the seed, and the size of the fruit is generally proportional to the number and size of seeds that develop (Nitsch, 1953). In the present study, large size fruit also had heavy, large seeds (Tables 3 and 4). Seeds of white sapote are used in traditional medicine (Satheesh, 2015), and this means that selecting genotypes producing larger fruit also means selecting genotypes able to produce large seeds. This is positive, considering that seeds could be used by the pharmaceutical industry. The NDS found in our study was within the range found in the 17 cultivars characterized by Yonemoto et al. (2001).

\section{Conclusions}

This is the first report in peer-reviewed literature regarding fruit and seed characteristics of white sapote growing in Mexico, which is one of the centers of origin of this species. The results indicate that there is an extremely high variability in the fruit and seed characteristics produced by different trees. This allows an initial preliminary individuation/selection of genotypes (trees number $49,17,31,41$, and 48) to be made with the aim of developing new cultivars for the establishment of white sapote orchards in Mexico. Among them, tree number 49 is very interesting because all of the parameters of both fruits and seeds were excellent. For a full characterization of these genotypes, it would be important to propagate them to establish a comparative field (ex situ) which will allow the best genotypes to be selected for developing white sapote cultivation in Mexico. Moreover, the large variability indicates that it would also be useful to expand the study to include other promising trees not considered in this initial investigation. Nutrimental characteristics and antioxidant activity in the pulp are also important to consider in future studies.

\section{Literature Cited}

Abo-El-Ez, A.T., D.M. Soltan, M.R. Gad-Elkareem, and E.H. Abdel-all. 2013. Evaluation and genetic diversity of three selected white sapote (Casimiroa edulis) clones under semi-arid climate. World Appl. Sci. J. 22(4):453-458.

Ahlawat, T.R., N.L. Patel, C.R. Patel, and R. Agnihotri. 2017. White sapote (Casimiroa edulis Llave \& Lex), Chapter 65, p.1353-1367. In: S.N. Ghosh, A. Singh, A. Thakur (eds.). Underutilized 
Table 4. Mean values of fourteen variables of 56 trees in the three groups of white sapote (Casimiroa edulis Llave \& Lex.) formed by cluster analysis.

\begin{tabular}{lrrrrrrrrrrrrrrc}
\hline Group & $N$ & \multicolumn{1}{c}{ FW } & HS & \multicolumn{1}{c}{ TSS } & \multicolumn{1}{c}{ SW } & PDF & EDF & NUS & NDS & TSW & SPA & LPA & LEA & SRI & FD \\
\hline 1 & 53 & 100.56 & 1.67 & 18.62 & 9.84 & 5.36 & 5.60 & 3.46 & 1.34 & 19.30 & 4.50 & 3.23 & 1.81 & 0.68 & 2.37 \\
2 & 2 & 26.76 & 0.92 & 19.85 & 3.59 & 3.48 & 3.14 & 2.50 & 2.17 & 1.99 & 1.31 & 1.80 & 0.91 & 0.63 & 1.25 \\
3 & 1 & 323.69 & 2.32 & 20.77 & 20.41 & 7.97 & 8.53 & 3.14 & 2.00 & 23.60 & 7.69 & 4.78 & 2.14 & 0.55 & 3.12 \\
\hline
\end{tabular}

$\mathrm{FW}=$ fruit fresh weight; $\mathrm{HS}=$ hardness of the skin; TSS = total soluble solids; $\mathrm{SW}=$ seed weight per fruit; $\mathrm{PDF}=$ polar diameter of the fruit; $\mathrm{EDF}=$ equatorial diameter of the fruit; NUS = number of undeveloped seeds; NDS = number of developed seeds; TSW = total seed weight per accession; SPA $=$ surface projected area of the seed; LPA = length of the polar axis of the seed; LEA = length equatorial of the seed; SRI = seed roundness index; $\mathrm{FD}=$ Feret diameter.

fruit crops: Importance and cultivation. 1st ed. Narendra Publishing House, India.

Andrés-Agustín, J. 1996. Cultivos alternativos para el estado de Michoacán: Identificación de algunas especies frutales promisorias. Rev. Geo. Agrí. 22-23:215-225.

Andrés-Agustín, J., F. González-Andrés, R. NietoAngel, and A.F. Barrientos-Priego. 2006. Morphometry of the organs of cherimoya (Annona cherimolla Mill.) and analysis of fruit parameters for the characterization of cultivars and Mexican germplasm selections. Scientia Hort. 107:337-346.

Chiang, F. 1989. Casimiroa greggii, formerly in Sargentia (Rutaceae). Taxon 38:116-119.

Crane, J.H. and C.F. Balerdi. 2016. White sapote growing in the home landscape. IFAS Extension, University of Florida. HS1054. 2 July 2016. <http://edis.ifas.ufl.edu/pdffiles/HS/ HS30400.pdf>.

De Sahagun, F. B. 1990. [c. 1582]. Historia general de las cosas de Nueva España. In: J.C. Temprano (ed.). Crónicas de América 55a-55b. Historia 16. Madrid.

Di Rienzo, J.A., F. Casanoves, M.G. Balzarini, L. González, M. Tablada, and C.W. Robledo. 2017. InfoStat versión 2017. Grupo InfoStat, FCA, Universidad Nacional de Córdoba, Argentina. 28 Feb. 2017. <https://www.infostat.com.ar/index. php? mod $=$ eventos\&month $=5 \&$ year $=2016>$.

Franco-Mora, O., E.J. Morales-Rosales, A. GonzálezHuerta, and J.G. Cruz-Castillo. 2008. Vegetative characterization of wild grapevines (Vitis spp.) native to Puebla, Mexico. HortScience 43:1991-1995.

García, M.R. 2007. La cuenca de México. Preclásico temprano y medio (2500-400 a.C.) las primeras sociedades agrícolas. Rev. Arqueol. Mex. 86:34-39.

George, A.P., R.J. Nissen, and D.J. Wallace. 1988. The casimiroa. Queensland Agr. J. 114(1):57-62.

González, A. 2001. La agricultura nahua en el siglo XVI. Revista Ciencia Ergo Sum 8:99107.
González-Elizondo, M.S., M. González-Elizondo, J.A. Tena-Flores, L. Ruacho-González, and I.L. López-Enríque. 2012. Vegetación de la Sierra Madre Occidental, México: Una síntesis. Acta Bot. Mex. 100:351-403.

Henry, A. and P. Vera-Calleti. 2010. Usages du sapotier blanc (Casimiroa spp.) en Mésoamérique. Histoire, ethnographie et botanique. Anthropobotanica 1.7:1-15.

Hernández, E. 1993. Aspects of plant domestication in Mexico: A personal view, p. 733-753. In: T.P. Ramamoorthy, R. Bye, and A. Lot. Biological diversity of Mexico: Origins and distribution. Oxford University Press, New York.

Khaleel, A.E.M. 2002. 2-phenyl-4-quinolinone alkaloids from Casimiroa edulis Llave \& Lex (Rutaceae). Chem. Monthly 133:183-187.

López-Santiago, J., R. Nieto-Angel, A.F. BarrientosPriego, E. Rodríguez-Pérez, M.T. Colínas-León, M.W. Borys, and F. González-Andrés. 2008. Morphological variable selection for hawthorn characterization (Crataegus spp.). Rev. Chapingo Ser. Hort. 14(2):97-111.

Lozano-Grande, M.A., S. Valle-Guadarrama, L.M. Marroquin-Andrade, and M.C. Ybarra-Moncada. 2006. Comportamiento en postcosecha de frutos de zapote blanco en Texcoco, México. Rev. Fitotec. Mex. 29(2):129-133.

Manly, B.F.J. 1986. Multivariate statistical methods a primer. Chapman and Hall, New York, NY.

Martinez, M. 1951. Las casimiroas de México y Centroamérica. Anales Inst. Biol. Univ. Nac. México 22(1):25-81.

Martínez, M.A., R. Ortega, and A. Cruz. 2013. Repercusiones de la introducción de la flora del Viejo Mundo en América y causas de la marginación de los cultivos. In: Cultivos AndinosFAO. <http://www.rlc.fao.org/es/agricultura/ produ/cdrom/contenido/libro09/Cap1_2.htm>.

Morton, J. 1987. White sapote, p. 191-196. In: J. Morton (ed.). Fruits of warm climates. Julia F. Morton, Miami, FL.

Nerd, A., J.A. Aronson, and Y. Mizrahi. 1990. Introduction and domestication of rare and wild fruit and nut trees for desert areas, p. 355-363. In: J. Janick and J.E. Simon (eds.). Advances in new crops. Timber Press, Portland, OR.

Nerd, A., M. Lapidot, and Y. Mizrahi. 1992. White sapote (Casimiroa edulis): Performance under various culture salinities and environmental stress conditions in field studies. Scientia Hort. 51(3-4):213-222.

Nitsch, J.P. 1953. The physiology of fruit growth. Annu. Rev. Plant Physiol. 4:199-236.

Popenoe, W. 1920. Manual of tropical and subtropical fruits. Hafner Press (Collier), New York, NY.

Rholf, F.J. 2000. NTSYSpc. Numerical taxonomy and multivariate analysis system. Version 2.1 . Exeter Software, New York, NY.

Rossini, O.S., B. Valdés, and F.M. Raimondo. 2002. Las plantas americanas en los jardínes de Sicilia occidental (Italia). Lagascalia 22:131144.

Satheesh, N. 2015. Review on distribution, nutritional and medicinal values of Casimiroa edulis Llave - An underutilized fruit in Ethiopia. Amer. Eurasian J. Agr. Environ. Sci. 15 (8):1574-1583.

Schneider, E. 1986. Uncommon fruits and vegetables. A common sense guide. Harper \& Row, New York, NY.

Thompson, P.H. 1972. The white sapote. California Rare Fruit Growers Nwsl. 4(3):1-12.

UTHSCSA, University of Texas Health Science Center San Antonio. 2000. Image tool. IT. Version 2.0. University of Texas, San Antonio, TX.

Vidal-López, D.G., M.A. Schlie-Guzmán, A.R González-Esquinca, and L. Luna-Cazáres. 2017. El zapote blanco (Casimiroa edulis Llave \& Lex, Rutaceae): Un recurso medicinal de México. Lacandonia 2(1):115-122.

Yamamoto, M., T. Tomita, K. Onjo, K. Ishihata, T. Kubo, and S. Tominaga. 2007. Genetic diversity of white sapote (Casimiroa edulis Llave \& Lex.) demostrated by intersimple sequence repeat analysis. HortScience 42:1329 1331.

Yonemoto, Y., H. Higuchi, K. Ishiharta, M. Ikeda, and E. Tomita. 2001. Analysis of varietal differences in floral and fruit morphology in white sapote (Casimiroa eduslis Llave \& Lex.). Jpn. J. Trop. Agr. 45:38-44.

Yonemoto, Y., K. Nomura, M. Ide, H. Inoue, M. Majikina, and H. Okuda. 2006. Index for harvesting time of white sapote (Casimiroa edulis Llave \& Lex.) cv. Cuccio. J. Hort. Sci. Biotech. 81:18-22.

Zavaleta, H.A. and E.M. Engleman. 1991. Anatomía del fruto de Casimiroa edulis (Rutaceae), "zapote blanco" durante su desarrollo. Bol. Soc. Bot. Mex. 51:53-65. 